\title{
Review Article \\ Modelling of Physical, Chemical, and Material Properties of Solid Oxide Fuel Cells
}

\author{
Jakub Kupecki \\ Thermal Processes Department, Institute of Power Engineering, Augustowka 36, 00-981 Warsaw, Poland \\ Correspondence should be addressed to Jakub Kupecki; jakub.kupecki@ien.com.pl
}

Received 29 September 2014; Revised 4 December 2014; Accepted 5 December 2014

Academic Editor: Xiao-Dong Wang

Copyright (C) 2015 Jakub Kupecki. This is an open access article distributed under the Creative Commons Attribution License, which permits unrestricted use, distribution, and reproduction in any medium, provided the original work is properly cited.

This paper provides a review of modelling techniques applicable for system-level studies to account for physical, chemical, and material properties of solid oxide fuel cells. Functionality of 0D to 3D models is discussed and selected examples are given. Author provides information on typical length scales in evaluation of power systems with solid oxide fuel cells. In each section, proper examples of previous studies done in the field of 0D-3D modelling are recalled and discussed.

\section{Introduction}

The development of innovative power systems requires continuous development of tools allowing modelling and simulation of their operation under different working conditions. Specific properties of solid oxide fuel cells related to physical, chemical, and material parameters enforce the need for advanced numerical models at different levels to account for numerous parameters. Different modelling methods are under considerations. Application-specific criteria and various designs require dedicated approach and methodology.

In general, models are used to help understanding the behaviour of a particular system in certain operating conditions and can be used to optimise control strategy, design, thermal balancing, and other parameters. Additionally, models can be used as predictive tools for performance evaluation under nonnominal conditions. Moreover, modelling followed by optimisation can provide crucial information for the improvements in the design and functionality. For this purpose steady state and/or dynamic evaluations can be performed. In this paper only the steady state operation is considered.

Validity range of different modelling techniques depends on the user-specified criteria. While in certain cases use of detailed 3D models might be required, in some situations simple reproduction of experimental data can be sufficient. Selection of method has to correspond to the purpose of the study, both including level of details and selection of either steady-state or transient analysis. In each case, determination of crucial criteria is an important step and must be done with caution.

In a comprehensive review of modelling methods by Ang et al. [1], the most commonly used approaches were discussed, including numerous parametric studies, single- and multiobjective optimisation. Indeed, the main purpose of any numerical study is to evaluate influence of and interactions between selected parameters. Optimisation always targets at finding the best operating mode when either one or more parameters are manipulated. Depending on the required complexity and level of details, different methods can be selected and used.

During SOFC-based system operation numerous processes are taking place at wide range of length- and timescales. Selection of a modelling method must be based on its capability of covering these processes in a sufficient way and with a required accuracy. Summary of typically considered phenomena with their corresponding length scales is presented in Table 1 after [2]. Additionally, corresponding time scales have to be taken into account while developing mathematical description of processes involved in transient 
TABLE 1: Different processes and their corresponding length scales [after 1].

\begin{tabular}{lll}
\hline $\begin{array}{l}\text { Scale } \\
{[\mathrm{m}]}\end{array}$ & Structure & Phenomena \\
\hline $10^{8}-10^{7}$ & $\begin{array}{l}\text { Electrode material, } \\
\text { triple phase } \\
\text { boundary-electrode }\end{array}$ & $\begin{array}{l}\text { Electrochemistry, diffusion } \\
\text { through the surface, chemical } \\
\text { reaction }\end{array}$ \\
\hline $10^{7}-10^{5}$ & Porous media & $\begin{array}{l}\text { Knudsen diffusion, flow through } \\
\text { porous media, chemical reaction }\end{array}$ \\
\hline $10^{5}-10^{3}$ & Flow field & $\begin{array}{l}\text { Diffusion, mass flow, heat } \\
\text { exchange }\end{array}$ \\
\hline $10^{3}-10^{2}$ & Single cell & $\begin{array}{l}\text { Transport of oxidant and fuel, } \\
\text { thermal balancing }\end{array}$ \\
\hline $10^{2}-10^{0}$ & Single cells/stack & $\begin{array}{l}\text { Electrical circuit of the cell/stack, } \\
\text { processes in the electrical system, } \\
\text { thermal balancing }\end{array}$ \\
\hline $10^{0}-10^{1}$ & System level & $\begin{array}{l}\text { Control, automatics, regulation, } \\
\text { safety systems, integration of the } \\
\text { entire system }\end{array}$ \\
\hline
\end{tabular}

analysis. This is especially important during dynamic modelling when proper time step has to be chosen.

Most of processes listed in Table 1 are also linked to specific time-scales. Grew and Chiu [3] discussed relations of particular length scales to various processes and experimental techniques.

Different approaches were analysed and developed over the years of SOFC research. In this paper methods applicable for larger length scales are mostly considered. Quantumand subatomic processes should not be neglected; however modelling at such scales is not in the scope of the paper.

In a valuable summary of modelling and simulation techniques for such length scales, Grew and Chiu [3] summarised applicable numerical and experimental methods, correlating different methods to the corresponding computational expense.

In general, analysis of SOFC at the stack level focuses on the development of models for electrochemical processes, chemical reactions, transport phenomena, and geometrical effects, such as the influence of a design of flow channels and their architecture. Investigation of the entire system typically includes studies on heat and mass exchange, electrical performance of equipment, and integration of the system.

In a recognised paper by Kakaç et al. [4] the most important issues related to SOFC modelling at different scales were reviewed and summarised. Indisputably, this paper can be used as an informative resource.

Transition between different approaches usually imposes selection of a suitable solution algorithm. For covering wide range of time- and length-scales, differential forms of governing equations can be transformed into discretised equations. For that purpose, different numerical methods such as Gauss elimination or tridiagonal matrix algorithm can be employed. Moreover, novel methods and in-house codes are developed. Selected processes can be modelled at sufficiently low computational cost with relatively simple methods, still providing high accuracy.

\section{Zero-Dimensional Modelling}

In selected situations, when focus is on large-scale effects, and taking into account that the spacial configuration is not required, discrete zero-dimensional methods of modelling can be used. This may apply to the overall electrochemistry, energy, and mass balances. In the simplest case, most components of a system can be modelled using performance curves or implemented characteristics. In a more comprehensive approach, advanced models can be applied in the 0D methodology. This modelling technique considers most of the system and its components as black boxes when only input-output specifications are of importance.

In some cases empirical and semiempirical formulas can be applied to correlate the outputs with inputs. General details of zero-dimensional modelling of energy systems are available in book by Badyda [5]. Selected reduced order models applied for high temperature fuel cells were discussed by Milewski et al. $[6,7]$.

Zero-dimensional approach is usually applicable for modelling cells, stacks, and for plant-level studies. In celllevel modelling the $0 \mathrm{D}$ approach can be efficiently used for solving elementary balance equations, that is, continuity, momentum, energy, and transport of species. Since solid oxide fuel cells consist of two porous electrodes separated by an electrolyte, porosity of these materials should be explicitly considered in the governing equations, and this can be easily done. Reduced-order models can be applied for evaluation of advanced architectures, including microstructural properties of electrodes [8]. Mass and ionic transport in microstructural graded materials was studied by $\mathrm{Ni}$ et al. [9] to evaluate effects of particle size and electrode thickness on overpotentials.

Once a set of equations is developed, it can be easily transferred into discrete $1 \mathrm{D}, 2 \mathrm{D}$, or 3D model, to be solved using one of available tools including in-house or commercial CFD codes [10]. Such models usually comprise certain assumptions, concerning constant composition of anodic and cathodic gases, and equilibrium of chemical reactions which take place. Despite the fact that applicability of zerodimensional modelling is limited, the approach proved to be robust, versatile, and precise. It provides relatively high accuracy with low prediction errors. Moreover, when optimisation is performed at the system level, these models are perfectly suitable to provide accurate qualitative and quantitative estimates. Bove and Ubertini [11] proposed using black-box models to investigate impact of fuel composition, cell overpotentials, oxidant, and fuel utilisation on the macroscopic performance of SOFC in terms of efficiency and characteristic curves. The work showed that the method is reliable and can be efficiently applied for solving complex problems. Such models should be used when system-level approach is required, without main focus on the microscale effects within the SOFC stack [12].

Among various models developed for studies on existing SOFC-based units, evidence of high fidelity $0 \mathrm{D}$ models of large systems can be found. Combined heat and power unit with nominal capacity of $100 \mathrm{~kW}_{\text {el }}$ located in Torino, Italy, was modelled by Calì et al. [13] with $0 \mathrm{D}$ steady state approach. In the work authors focused on finding factors 
of a high importance for system performance, rather than analysing in detail physical and chemical relations between microscale phenomena involved in operation of the unit. Zero-dimensional approach aids in performing parametric studies of SOFC performance with electrochemical models taking into account operational and structural parameters to correlate overpotentials with geometry and working conditions [14].

Generally, plant-level modelling is necessary to investigate particular applications. Such models can also provide predictive information about specific subsystems, including fuel cell stack, fuel supply and processing, water, fuel and heat management, power conditioning, and control equipment. These subsystems can and should be selected for optimisation [1], since only high performance of all components can assure overall system efficiency at satisfactory level. In such manner, material properties of solid oxide fuel cells were evaluated using zero-dimensional model developed specifically for plant-level simulations [15].

Zero-dimensional models can be easily built and executed in one of popular commercial codes such as Aspen HYSYS, Aspen Plus, gPROMS, and others, including user routines developed in common programming languages. Some of the listed codes exhibit unique features which can be useful in modelling of electrochemical energy conversion devices, such as fuel cells. Among the ones listed, Aspen HYSYS is an example of a versatile tool capable of modelling different components, machinery, chemical, and electrochemical processes. Aspen HYSYS offers a comprehensive foundation for accurate calculations of the physical properties and thermodynamic and transport properties in most technological and chemical processes. Software proved to be capable of handling very advanced and complex power systems with solid oxide fuel cells [16].

\section{One- and Two-Dimensional Modelling}

One- and two-dimensional models (1D and 2D) are typically used when effects of geometry have to be taken into account. This group of models is usually used to reduce computational cost typical for solving fully three-dimensional models. It is mostly done in situations when discretisation of partial and ordinary differential equations does not substantially compromise accuracy of the model, even when the geometry is simplified to a certain extent.

1D and 2D models can be applied for evaluation of distribution of parameters along the flow channels for different domains in a fuel cell: fuel and air stream, anode-electrolytecathode structure, and interconnects. Mass transport in fuel and air gas channels can be treated as a fully developed laminar flow described sufficiently by means of velocity and temperature. Flow patterns within fuel cell channels were previously studied, and laminar character was found to be indeed a proper assumption [2]. Additionally, in the systemlevel studies, one- and two-dimensional models can help to evaluate thermal integration of components. Detailed information about interactions within the system structure can support the designing process and contribute to maximisation of the system performance. Analysis of thermal and chemical properties requires high attention especially during part-load operation of systems with fuel cells. Endothermic and exothermic processes have to be precisely balanced and thermal losses have to be compensated.

In previous studies good evidence of using $1 \mathrm{D}$ and $2 \mathrm{D}$ approaches to SOFC stacks can be found. Lai et al. [17] used the technique and developed tool suitable for analysis of SOFC stack containing up to 100 cells. They derived a model where set of conservation equations was solved for $1 \mathrm{D}$ case and later extrapolated for the entire stack; hence quasi-2D model was obtained. Moreover, to allow simulation of broad range of cells, user-defined electrochemical model was employed. An in-house code, based on subroutines, was implemented in FORTRAN, with typical tolerances for temperature and current of 0.1 and $1 \%$, respectively. Predictions of the model for the benchmark cases with and without on-cell methane reforming were compared with results from other studies described in the literature, and good agreement was achieved.

The approach also finds application in predicting distribution of chemical species and evaluation of temperature profiles. Mahcene et al. [18] used 2D tool to model coflow planar anode supported SOFC as a single unit and studied influence of the porosity of a thick $(500 \mu)$ anode on a cell performance.

In work by Jewulski et al. [19] flow distribution of reactants was studied using $2 \mathrm{D}$ model. Simulation of the gas flow, local fuel utilisation, and pressure distribution in the internally manifolded stack showed good results and agreement with the analytical model. Moreover, 2D tool was sufficient to obtain convergence with experimental data.

Summarising, one- and two-dimensional models can be employed both at the micro- and macroscales in order to analyse most of phenomena ranging from flow patterns in the microporous structures of fuel cell assemblies up to the integration of components at the system-level.

\section{Three-Dimensional Modelling and Computational Fluid Dynamics Codes}

The most comprehensive approach, which can be used for simulation of most processes involved in power generation in SOFC-based system, is the fully three-dimensional modelling. Method is relevant for most issues listed previously in Table 1. Moreover, such approach can be used not only to aid in designing, evaluation, and optimisation of system components, but also for studies related to interactions between them. By these mean spacial arrangements, thermal balancing and integration of system components can be improved for high overall performance. Applicability range of fully 3D models is theoretically unlimited; however computational cost might be the limiting factor. Typically, this approach is selected only for detailed analysis of a particular structure or process. Moreover, high computational cost makes these models not suitable for evaluation of the system during dynamic operation, and mostly single operational point is investigated.

Among available literature on 3D modelling of different aspects of solid oxide fuel cells, selected papers on the topic 
should be noted. In early 1990s, Achenbach [20] employed numerical tool to investigate heat conductivity of a stack for ceramic and metallic plates. With the proposed methodology it was possible to compute overall heat conductivities of these materials. Values of $2 \mathrm{~W} \mathrm{~m}^{-1} \mathrm{~K}^{-1}$ and $27 \mathrm{~W} \mathrm{~m}^{-1} \mathrm{~K}^{-1}$ were found for the former and latter, respectively. Additionally, model was used to evaluate radiation influence on the total amount of heat generated by the stack. Depending on the material, radiation accounted to $7 \%$ and $22 \%$ of total heat losses from ceramic and metallic stack, respectively. In work by Tanaka et al. [21] detailed study on SOFC stack was performed. Authors investigated heat exchange, with special focus on heat radiation within the stack. Numerical tool, which allowed to precisely predict temperature distribution in flow channels, was developed and used in the study. Additionally, tool was employed to determine average single cell voltage for different ambient conditions.

Kattke et al. [22] modelled highly integrated SOFCbased system with 3D approach combined with 1D model of a tubular SOFC stack. In the work quasi-one-dimensional model was used to simulate balance of plant (BoP) components, including catalytic partial oxidation fuel processor and tail gas combustor. Integration and interactions between system components were studied using computational fluid dynamic code. The prototype unit with nominal gross power of $650 \mathrm{~W}_{\mathrm{el}}$ was simulated. This methodology was one of a very few approaches, when interactions between micro-CHP system components were of a high attention. Paper should be considered as a highly valuable contribution due to the fact that previously nobody really studied influence of SOFC stack on the other system components located close to each other. Generally, the work was merging scientific approach with aspects related to the design and construction; therefore it is a good resource for the development of solutions for problems handled by mathematical models of fuel cells. Moreover, the approach proposed by Kattke et al. was actually addressing another major issue. In vast majority of previous studies, adiabatic SOFC stack was considered; however such approach has no physical meaning, and cannot be applied for analysis of systems.

Fully three-dimensional models can allow evaluation of SOFC-based system without oversimplifying or even neglecting certain aspects. System design and simulation models found in the extant literature typically employ approaches that either

(i) assume adiabatic conditions for components of a system [23],

(ii) employ thermodynamic models to predict the required heat loss from components based on a given inlet and outlet state [12], or

(iii) calculate component heat losses without any thermal coupling [23-25].

Such approaches do not allow to capture the thermofluidic interactions between components nor do they quantify the effect of thermal coupling on the system performance. Generally significant thermal interactions are found especially in micro- and small-scale units, including portable and mobile applications. For this purpose, Kattke and Braun [26] implemented thermal management modelling tool into a system model that includes interactions between components for small, mobile application based on planar SOFC, using relatively simple thermal resistance approach. The study showed how oversimplified the oxidant flow requirement, recuperator heat duty, and other parameters could be when heat exchange by convection and radiation is neglected. Summarising, in a general case, for all computational approaches and different solution algorithms, the following input information must be specified by the user to account for

(i) cell's geometry and parameters (number and design of flow channels, their dimensions, length, width, and height of cell, thickness of interconnects, material types, and their properties, etc.),

(ii) thermodynamic state (temperature and pressure) and composition of fuel and oxidant at the inlet,

(iii) boundary conditions (temperature of the surrounding top, bottom, front, back, and side enclosures including thermal conductivity, emissivity, and other thermal parameters),

(iv) operating conditions of cells in different working modes.

The model should be capable of solving the multiphysics system and predict the following information for the SOFC system:

(i) overall SOFC stack performance: total power output, fuel and air utilisation, heat loss at each side of the boundary, working voltage, and current density for each cell in the stack,

(ii) detailed profiles of various thermophysical parameters: temperature, current density, species composition, and heat generation in each control volume (fuel, air, positive-electrolyte-negative (PEN) structures, and interconnects).

For this purpose, hybrid multidimensional models are often used. Certain components are treated with quasi-onedimensional approach, while the other are treated with $1 \mathrm{D}$ or $2 \mathrm{D}$ technique. Despite the fact that such methodology allows covering most of the occurring phenomena, at this point question may arise if the reliability level of the model is sufficient. In any case, results should be validated with experimental data or at least verified by comparison with alternative models. Razbani et al. [27] performed experimentally validated numerical analysis of electrolyte supported six-cell SOFC stack fed by biogas using 3D modelling in COMSOL Multiphysics. Comprehensive CFD models find application in simulation of fuel cells with different supports, both for high [28] and for intermediate temperature designs [29].

Several papers present results of modelling of fuel processing, including internal reforming [30] and partial prereforming of different gas mixtures [31]. Studies on direct internal reforming in solid oxide fuel cells require coupling of models for electrochemical and catalytic processes with 
simulation of mass transfer in porous media. For that reason either $2 \mathrm{D}$ or $3 \mathrm{D}$ models are used for solving the elementary mass and energy balances and evaluation of transport in porous media.

If decision is made to analyse the entire system by solving sets of fully 3D governing equations, computer codes such as Ansys Fluent, Ansys CFX, Open FOAM, Cantera, Python, and in-house software can be used. High computational expense, enormous number of nodes, and other factors usually justify selection of simplified methods.

\section{Investigation of Manifolds Geometry}

Solid oxide fuel cells are currently fabricated by number of producers in Europe, America, and Asia. Different types of geometries, sizes, materials, and manufacturing methods are viable. Performance of a cell depends on the way oxidant and fuel are supplied to the cell. This directly influences distribution of species, thermal and pressure gradients, and finally voltage and current density.

The generic solid oxide fuel cell can be arranged in one of multiple configurations. Typical geometries are either rectangular (usually square) or circular. Square cell offers four main options for species distribution with the manifold:

(i) cross-flow,

(ii) co/counter-flow,

(iii) Z-flow,

(iv) serpentine flow.

The manifolds for a circular cell are designed either in radial or spiral-flow configuration. Each of the configurations enables different operational characteristics. Disadvantages typically include large temperature gradients, mostly in counter-flow configurations. Several studies were addressing issues connected with manifold geometries. In the early 1990s Achenbach [20] studied cell performance depending on the geometry. Cross-, counter-, and coflow cells were analysed with 3D model. Temperature gradients, mean stack temperature, and current density in different flow configurations were investigated. This study clearly indicated that cross-flow configuration is an optimal choice due to the fact that relatively even distribution of temperature can be achieved. With focus on current and temperature distribution Iwata et al. [32] performed comparative analysis of planar SOFC investigating cross-, counter- and coflows. This work showed potential of numerical tool considering Nernst voltage and overpotential changes along flow channels. Cross-flow configuration was once again found the optimal.

\section{Fluctuations of SOFC Parameters}

In addition to the previously discussed aspects of solid oxide fuel cells, studies related to fluctuations of cell parameters should be mentioned. Operational parameters of SOFCs slightly vary over short time intervals and on longer time horizons. Slow changes of characteristics can be observed due to SOFC performance degradation. Certain external parameters might also influence operation of SOFC-based power systems. Work by Tanaka et al. [21] of AIST, Japan, should be noted for elaboration on certain fluctuations during operation of a small-scale cogenerative SOFC-based unit. Authors performed detailed uncertainty estimation for $10 \mathrm{~kW}_{\mathrm{el}}$-class units fed by natural gas. Research was focused on evaluation of possible fluctuations, including change of fuel quality over time (i.e., deviation of $\mathrm{HHV}$ from the nominal value), flow variations, precision of the measurement equipment, and other factors. The outcome of this investigation was the indication that electrical efficiency of the system can be determined with $1.0 \%$ relative uncertainty at $95 \%$ level of confidence for stable operation. Moreover, it should be emphasised that $\pm 1 \%$ electrical efficiency change might influence payback times and economic feasibility of the technology. In a similar manner, calculations can be performed for other technologies; however fuel cells are generally believed to operate in a much stable manner compared with other energy conversion systems [33].

\section{Influence of Various Fuels and Fuel Processing Technologies}

It is well know that the main advantage of solid oxide fuel cells is the ability to operate with number of different fuels including:

(i) alcohols [34],

(ii) hydrocarbons [33],

(iii) pure hydrogen $[35,36]$,

(iv) biofuels [37],

(v) liquid energy carriers which can be converted to hydrogen-rich gas, including ammonia [38-40] and dimethyl ether $[41,42]$,

(vi) landfill gas [43].

Most of fuels listed above require control of steam-tocarbon ration in the fuel processor to prevent soot formation and deposition in the fuel line.

Several other studies included evaluation of operation of proton and oxygen ion conducting fuel cells fed by alternative fuels, including methane [44]. Nonetheless, in order to assure high performance and long-lasting operation of a fuel cell stack, proper fuel processing technology has to be selected.

Typical requirements for the fuel processor include

(i) high conversion of the fuel,

(ii) high hydrogen selectivity,

(iii) stability against rapid changes of the gas composition and flow,

(iv) low catalyst degradation over time,

(v) stability against passivation and deactivation due to poisoning,

(vi) easy thermal integration and possibility to operate with slight and major temperature variations expected during transients, 
TABLE 2: Existing literature on selected topical areas of modelling SOFCs.

\begin{tabular}{|c|c|c|}
\hline Topical area & Literature & Comments \\
\hline $\begin{array}{l}\text { Multilevel } \\
\text { modelling }\end{array}$ & $1-5,11$ & $\begin{array}{l}\text { Design point, off-design, and } \\
\text { transient operation of standalone } \\
\text { SOFC stacks }\end{array}$ \\
\hline $\begin{array}{l}\text { Alternative } \\
\text { fuels }\end{array}$ & $\begin{array}{l}34-45,28, \\
29,35 \\
38-40,43, \\
44\end{array}$ & $\begin{array}{l}\text { Selected aspects of fuel processing, } \\
\text { typical impurities, and clean-up } \\
\text { systems }\end{array}$ \\
\hline Reforming & $31,32,42$ & $\begin{array}{l}\text { Internal, external, and partial } \\
\text { prereforming }\end{array}$ \\
\hline $\begin{array}{l}\text { Effects of } \\
\text { working } \\
\text { conditions }\end{array}$ & $\begin{array}{l}18,29,31, \\
33\end{array}$ & $\begin{array}{l}\text { Effects of temperature, pressure, and } \\
\text { fuel composition }\end{array}$ \\
\hline Thermal effects & $\begin{array}{l}18,20-22 \\
27,29\end{array}$ & $\begin{array}{l}\text { Evaluation of different heat transfer } \\
\text { phenomena in manifolds, stacks, and } \\
\text { single cells }\end{array}$ \\
\hline $\begin{array}{l}\text { Different } \\
\text { architectures }\end{array}$ & $\begin{array}{l}7-10,17 \\
22,30,36 \\
40,44\end{array}$ & $\begin{array}{l}\text { Planar and tubular designs, varied } \\
\text { thickness of interlayers and different } \\
\text { materials }\end{array}$ \\
\hline Degradation & $\begin{array}{l}35,36,38, \\
46\end{array}$ & $\begin{array}{l}\text { Degradation mechanisms due to } \\
\text { impurities and thermal cycling }\end{array}$ \\
\hline $\begin{array}{l}\text { System-level } \\
\text { studies }\end{array}$ & $\begin{array}{l}12,13,15 \\
16,22-25 \\
42\end{array}$ & $\begin{array}{l}\text { Evaluation of the influence of single } \\
\text { cell properties on the entire power } \\
\text { unit }\end{array}$ \\
\hline
\end{tabular}

(vii) compact size,

(viii) mechanical stability against thermal gradients allowing relatively quick start-up of the reformer.

Generally, three different technologies can be distinguished for converting raw fuel before it enters the SOFC stack, namely, catalytic partial oxidation (CPOX), steam reforming (SR), and autothermal reforming (ATR). In certain cases these processes can be accompanied by fuel cleanup and conditioning stages as it is usually done for fuels containing significant amounts of sulphur compounds, such as hydrogen sulphide or odorants. Selected aspects and effects of impurities are discussed in a paper by Błesznowski et al. [45].

\section{Conclusions}

Major issues related to physical, chemical, and material properties of solid oxide fuel cells are discussed in the paper. Author provides review of modelling techniques applicable for evaluation and determination of selected properties. Based on the review, eight topical areas related to modelling and simulation of solid oxide fuel cells can be distinguished: (I) multilevel modelling, (II) alternative fuels for cells, stacks, and complete systems, (III) reforming, (IV) effects of working conditions, (V) thermal effects, (VI) different architectures, (VII) degradation, and (VIII) system-level studies. Summary of relevant literature can be seen in Table 2.

Depending on the required level of details, different approaches can be used to simulate operation of a stand-alone fuel cell (either a single cell or a short stack) or complete power systems. Alternative complimentary modelling methods can be used simultaneously to investigate wide range of processes, with respect to the purpose of an analysis.

Eventually, it can be concluded that selection of particular modelling methodology is a trade-off between precision and computational cost. According to the literature considered in this paper, number of simplifying assumptions can be used to adapt $0 \mathrm{D}$ or $1 \mathrm{D}$ models to investigate physical, thermal, and chemical processes related to operation of solid oxide fuel cell. Reduced order lumped volume models allow simplifying the description of the behaviour of spatially distributed systems with SOFCs into discrete modules, hence allowing effective and quick numerical simulations. In all situations, the acceptable level of precision should be defined before particular modelling methodology is used.

\section{Conflict of Interests}

The author declares that there is no conflict of interests regarding the publication of this paper.

\section{Acknowledgment}

This work was supported by The National Centre for Research and Development in frame of Strategic Programme Advanced Technologies for Energy Generation.

\section{References}

[1] S. M. C. Ang, E. S. Fraga, N. P. Brandon, N. J. Samsatli, and D. J. L. Brett, "Fuel cell systems optimisation-methods and strategies," International Journal of Hydrogen Energy, vol. 36, no. 22, pp. 14678-14703, 2011.

[2] J. Kupecki, J. Jewulski, and J. Milewski, "Multi-level mathematical modeling of solid oxide fuel cells," in Clean Energy for Better Environment, pp. 53-85, Intech, Rijeka, Croatia, 2012.

[3] K. N. Grew and W. K. S. Chiu, "A review of modeling and simulation techniques across the length scales for the solid oxide fuel cell," Journal of Power Sources, vol. 199, pp. 1-13, 2012.

[4] S. Kakaç, A. Pramuanjaroenkij, and X. Y. Zhou, "A review of numerical modeling of solid oxide fuel cells," International Journal of Hydrogen Energy, vol. 32, no. 7, pp. 761-786, 2007.

[5] K. Badyda, Mathematical Modelling of Power Systems, Publishing House of Warsaw University of Technology, 2001.

[6] J. Milewski and K. Świrski, "Artificial neural network-based model for calculating the flow composition influence of solid oxide fuel cell," Journal of Fuel Cell Science and Technology, vol. 11, no. 2, Article ID 021001, 2014.

[7] J. Milewski, M. Wołowicz, R. Bernat, Ł. Szabłowski, and J. Lewandowski, "Variant analysis of the structure and parameters of SOFC hybrid systems," Applied Mechanics and Materials, vol. 437, pp. 306-312, 2013.

[8] X. J. Chen, S. H. Chan, and K. A. Khor, "Simulation of a composite cathode in solid oxide fuel cells," Electrochimica Acta, vol. 49, no. 11, pp. 1851-1861, 2004.

[9] M. Ni, M. K. H. Leung, and D. Y. C. Leung, "Micro-scale modelling of solid oxide fuel cells with micro-structurally graded electrodes," Journal of Power Sources, vol. 168, no. 2, pp. 369378, 2007. 
[10] M. Karcz, "From 0D to 1D modeling of tubular solid oxide fuel cell," Energy Conversion and Management, vol. 50, no. 9, pp. 2307-2315, 2009.

[11] R. Bove and S. Ubertini, "Modeling solid oxide fuel cell operation: approaches, techniques and results," Journal of Power Sources, vol. 159, no. 1, pp. 543-559, 2006.

[12] P. Lisbona, A. Corradetti, R. Bove, and P. Lunghi, "Analysis of a solid oxide fuel cell system for combined heat and power applications under non-nominal conditions," Electrochimica Acta, vol. 53, no. 4, pp. 1920-1930, 2007.

[13] M. Calì, M. G. L. Santarelli, and P. Leone, "Computer experimental analysis of the CHP performance of a $100 \mathrm{~kW}_{e}$ SOFC Field Unit by a factorial design," Journal of Power Sources, vol. 156, no. 2, pp. 400-413, 2006.

[14] M. Ni, M. K. H. Leung, and D. Y. C. Leung, "Parametric study of solid oxide fuel cell performance," Energy Conversion and Management, vol. 48, no. 5, pp. 1525-1535, 2007.

[15] J. Kupecki, J. Milewski, and J. Jewulski, "Investigation of SOFC material properties for plant-level modeling," Central European Journal of Chemistry, vol. 11, no. 5, pp. 664-671, 2013.

[16] J. Kupecki, J. Milewski, K. Badyda, and J. Jewulski, "Evaluation of sensitivity of a micro-CHP unit performance to SOFC parameters," ECS Transactions, vol. 51, no. 1, pp. 107-116, 2013.

[17] K. Lai, B. J. Koeppel, K. S. Choi et al., "A quasi-two-dimensional electrochemistry modeling tool for planar solid oxide fuel cell stacks," Journal of Power Sources, vol. 196, no. 6, pp. 3204-3222, 2011.

[18] H. Mahcene, H. B. Moussa, H. Bouguettaia, D. Bechki, S. Babay, and M. S. Meftah, "Study of species, temperature distributions and the solid oxide fuel cells performance in a 2-D model," International Journal of Hydrogen Energy, vol. 36, no. 6, pp. 4244-4252, 2011.

[19] J. Jewulski, M. Blesznowski, and M. Stepien, "Flow distribution analysis of the solid oxide fuel cell stack under electric load conditions," in Proceedings of the 9th European Solid Oxide Fuel Cell Forum, Lucerne, Switzerland, 2009.

[20] E. Achenbach, "Three-dimensional and time-dependent simulation of a planar solid oxide fuel cell stack," Journal of Power Sources, vol. 49, no. 1-3, pp. 333-348, 1994.

[21] T. Tanaka, Y. Inui, A. Urata, and T. Kanno, "Three dimensional analysis of planar solid oxide fuel cell stack considering radiation," Energy Conversion and Management, vol. 48, no. 5, pp. 1491-1498, 2007.

[22] K. J. Kattke, R. J. Braun, A. M. Colclasure, and G. Goldin, "Highfidelity stack and system modeling for tubular solid oxide fuel cell system design and thermal management," Journal of Power Sources, vol. 196, no. 8, pp. 3790-3802, 2011.

[23] M. Sorrentino and C. Pianese, "Control oriented modeling of solid oxide fuel cell auxiliary power unit for transportation applications," Journal of Fuel Cell Science and Technology, vol. 6, no. 4, 12 pages, 2009.

[24] N. Lu, Q. Li, X. Sun, and M. A. Khaleel, "The modeling of a standalone solid-oxide fuel cell auxiliary power unit," Journal of Power Sources, vol. 161, no. 2, pp. 938-948, 2006.

[25] S. H. Chan and O. L. Ding, "Simulation of a solid oxide fuel cell power system fed by methane," International Journal of Hydrogen Energy, vol. 30, no. 2, pp. 167-179, 2005.

[26] K. J. Kattke and R. J. Braun, "Implementing thermal management modeling into SOFC system level design," Journal of Fuel Cell Science and Technology, vol. 8, no. 2, Article ID 021009, 2011.

[27] O. Razbani, M. Assadi, and M. Andersson, "Three dimensional CFD modeling and experimental validation of an electrolyte supported solid oxide fuel cell fed with methane-free biogas," International Journal of Hydrogen Energy, vol. 38, no. 24, pp. 10068-10080, 2013.

[28] J. Park, P. Li, and J. Bae, "Analysis of chemical, electrochemical reactions and thermo-fluid flow in methane-feed internal reforming SOFCs: part II-temperature effect," International Journal of Hydrogen Energy, vol. 37, no. 10, pp. 8532-8555, 2012.

[29] D. H. Jeon, "A comprehensive CFD model of anode-supported solid oxide fuel cells," Electrochimica Acta, vol. 54, no. 10, pp. 2727-2736, 2009.

[30] V. M. Janardhanan and O. Deutschmann, "CFD analysis of a solid oxide fuel cell with internal reforming: coupled interactions of transport, heterogeneous catalysis and electrochemical processes," Journal of Power Sources, vol. 162, no. 2, pp. 1192 $1202,2006$.

[31] M. Ni, "Modeling of SOFC running on partially pre-reformed gas mixture," International Journal of Hydrogen Energy, vol. 37, no. 2, pp. 1731-1745, 2012.

[32] M. Iwata, T. Hikosaka, M. Morita et al., "Performance analysis of planar-type unit SOFC considering current and temperature distributions," Solid State Ionics, vol. 132, no. 3, pp. 297-308, 2000.

[33] US Department of Energy Office of Fossil Energy National Energy Technology Laboratory, Fuel Cell Handbook, EG\&G Technical Services, Inc., 7th edition, 2004.

[34] Y. Jiang and A. V. Virkar, "A high performance, anodesupported solid oxide fuel cell operating on direct alcohol," Journal of the Electrochemical Society, vol. 148, no. 7, pp. A706A709, 2001.

[35] H. Yokokawa, "Understanding materials compatibility," Annual Review of Materials Research, vol. 33, pp. 581-610, 2003.

[36] R. O'Hayre, S. W. Cha, W. Colella, and F. Prinz, Fuel Cell Fundamentals, Wiley, 2005.

[37] J. Staniforth and R. M. Ormerod, "Running solid oxide fuel cells on biogas," Ionics, vol. 9, no. 5-6, pp. 336-341, 2003.

[38] A. Wojcik, H. Middleton, I. Damopoulos, and J. van Herle, "Ammonia as a fuel in solid oxide fuel cells," Journal of Power Sources, vol. 118, no. 1-2, pp. 342-348, 2003.

[39] M. Ni, D. Y. C. Leung, and M. N. K. Leung, "Mathematical modeling of ammonia-fed solid oxide fuel cells with different electrolytes," International Journal of Hydrogen Energy, vol. 33, no. 20, pp. 5765-5772, 2008.

[40] M. Ni, D. Y. C. Leung, and M. K. H. Leung, "Electrochemical modeling of ammonia-fed solid oxide fuel cells based on proton conducting electrolyte," Journal of Power Sources, vol. 183, no. 2, pp. 687-692, 2008.

[41] J. Kupecki, J. Jewulski, and K. Badyda, "Comparative study of biogas and DME fed micro-CHP system with solid oxide fuel cell," Applied Mechanics and Materials, vol. 267, pp. 53-56, 2013.

[42] E. P. Murray, S. J. Harris, and H. Jen, "Solid oxide fuel cells utilizing dimethyl ether fuel," Journal of the Electrochemical Society, vol. 149, no. 9, pp. A1127-A1131, 2002.

[43] M. Ni, "Is steam addition necessary for the landfill gas fueled solid oxide fuel cells?" International Journal of Hydrogen Energy, vol. 38, no. 36, pp. 16373-16386, 2013.

[44] M. Ni, D. Y. C. Leung, and M. K. H. Leung, "Modeling of methane fed solid oxide fuel cells: comparison between proton conducting electrolyte and oxygen ion conducting electrolyte," Journal of Power Sources, vol. 183, no. 1, pp. 133-142, 2008.

[45] M. Błesznowski, J. Jewulski, and A. Zieleniak, "Determination of $\mathrm{H}_{2} \mathrm{~S}$ and $\mathrm{HCl}$ concentration limits in the fuel for anode supported SOFC operation," Central European Journal of Chemistry, vol. 11, no. 6, pp. 960-967, 2013. 

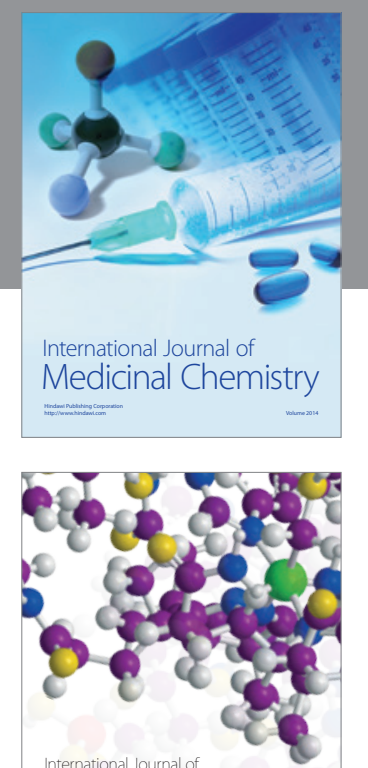

\section{Carbohydrate} Chemistry

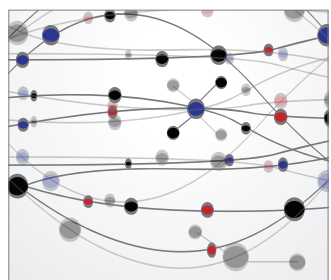

The Scientific World Journal
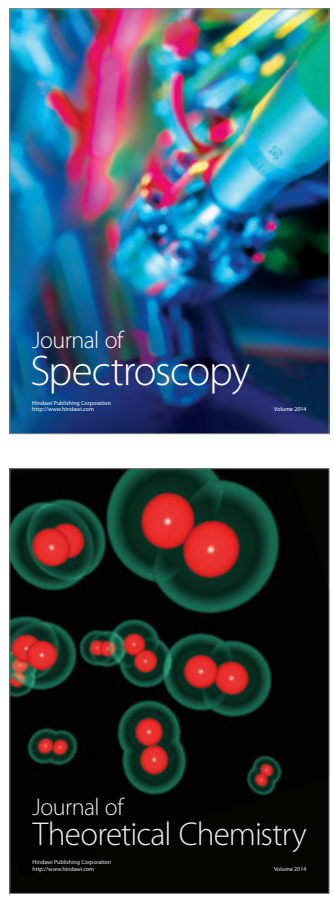
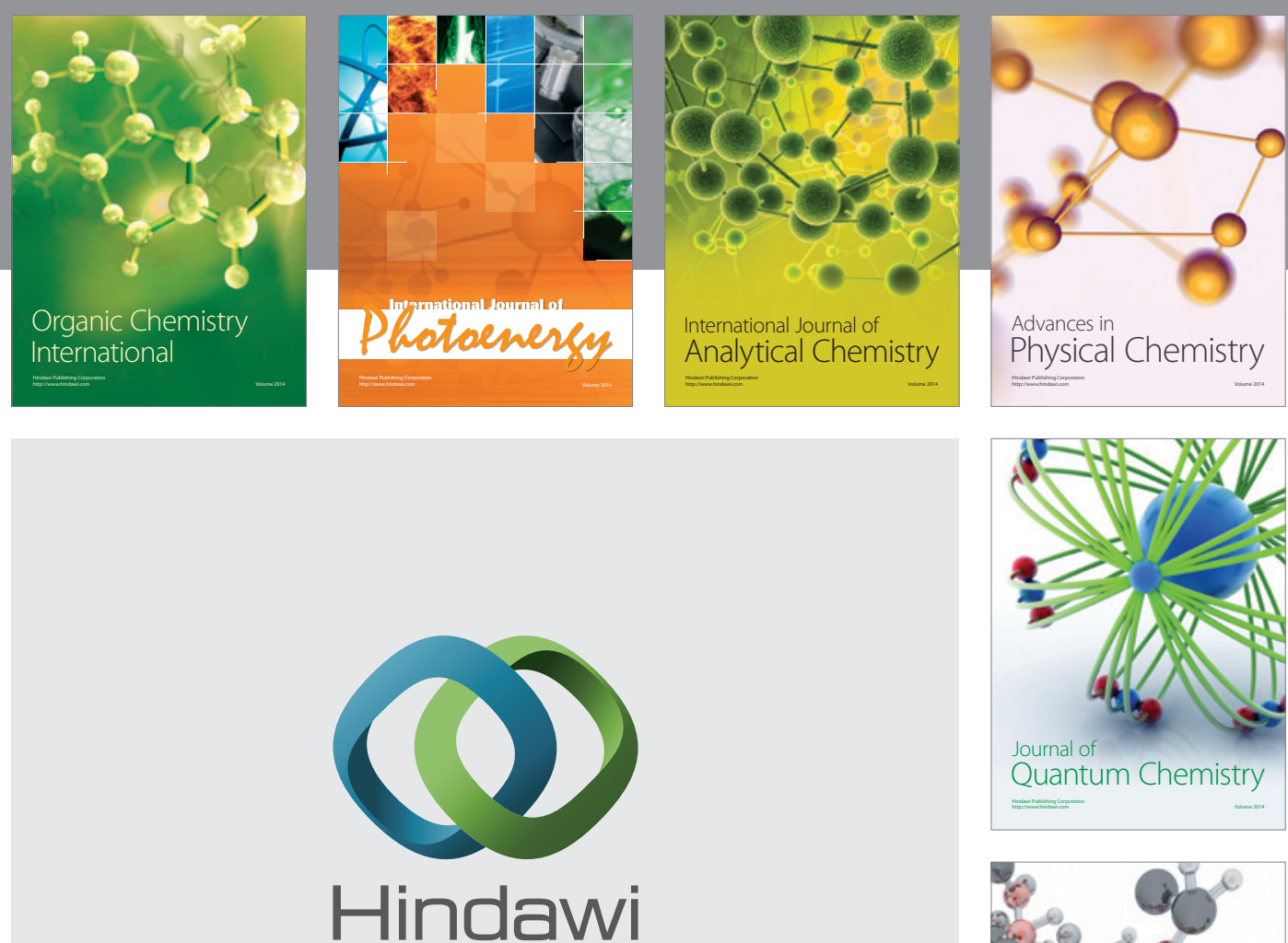

Submit your manuscripts at

http://www.hindawi.com

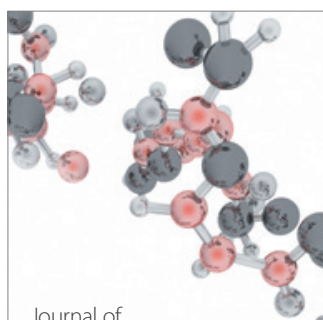

Analytical Methods

in Chemistry

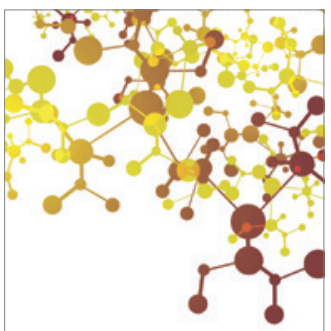

Journal of

Applied Chemistry

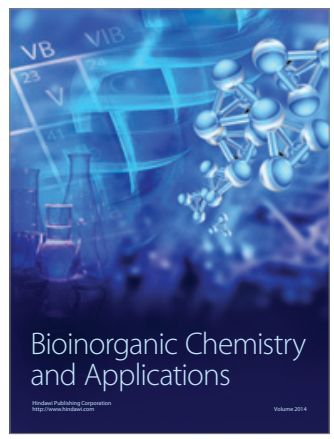

Inorganic Chemistry
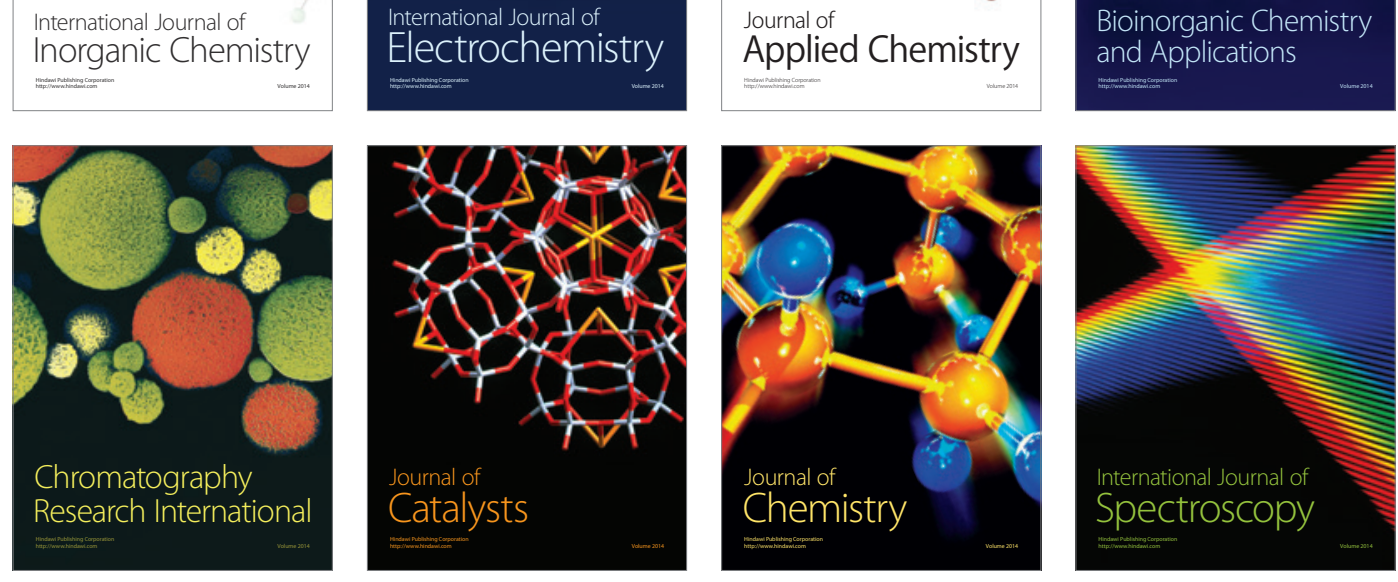